\begin{tabular}{|c|c|}
\hline \multirow{3}{*}{ 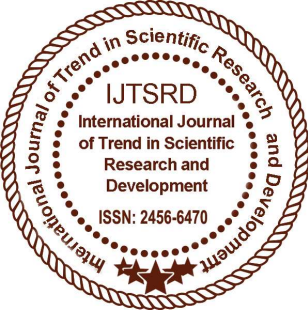 } & $\begin{array}{l}\text { International Journal of Trend in Scientific } \\
\text { Research and Development (IJTSRD) }\end{array}$ \\
\hline & International Open Access Journal \\
\hline & ISSN No: 2456 - 6470 | www.ijtsrd.com | Volume - 2 | Issue - 4 \\
\hline
\end{tabular}

\title{
Performance Improvement Analysis on PV/T Solar Water Collectors Connected in Series and Parallel
}

\author{
S. Paramaguru, P. Sivakumar, M. Sridharan, Dr. T. Senthilkumar \\ Department of Mechanical Engineering, University College of Engineering, \\ BIT Campus, Tiruchirappalii, Tamil Nadu, India
}

\section{ABSTRACT}

The solar panel is one of the most sought after methods to produce electrical energy for domestic purposes. Solar PV/T systems converts solar irradiation into thermal and electrical energy. Module is made of Poly c-Si material. This experiment aims at analysing the comparative performance of hybrid solar PV/T water collectors connected in series and parallel. It was conducted in Saranathan College of Engineering, Tiruchirapalli-12. It is located at latitude of $10.7560^{\circ} \mathrm{N}$ and longitude of $78.6513^{\circ} \mathrm{E}$. The maximum temperature of water obtained was $42.8^{\circ} \mathrm{C}$ and $40.8^{\circ} \mathrm{C}$ respectively in series and parallel. Overall the parallel connected PV/T system's performance is $12.12 \%$ higher than the series connected PV/T system.

Keywords: Solar, PV/T, Unglazed, Series, Parallel etc.

\section{INTRODUCTION}

Solar is the best form of renewable energy which is widely used all around the world currently. Solar energy is used for many domestic purposes but it has its own snags. Current dollar technology only converts electricity with a maximum efficiency of about $25 \%$. This is because of occurrence of thermal degradations like non uniform cooling, high operating temperature of the panel, dust accumulation on the panel. The performance made by forced circulation mode gives the output water temperature around 0.5 $2.5^{\circ} \mathrm{C}$ from parallel configuration which is higher than the series[1].
In order to avoid dust accumulation the pitch angle should be set to zero early morning or late in the evening to drop slide off the dust[2]. The electrical efficiency is increased and cell degradation is reduced with time by proper cooling.

Without active cooling the temperature of module was high and with cooling the temperature dropped significantly [3-4]. Use of nano fluid is also experimented but it is economically costly and there is a change of thermal properties of a $3 \%$ nano fluid (SiC) on viscosity (1.8\%); thermal conductivity $(8.2 \%)$; density $(0.0082 \%)$ and thermal conductivity of nano particles was increased up to $4.3 \%$ [5].

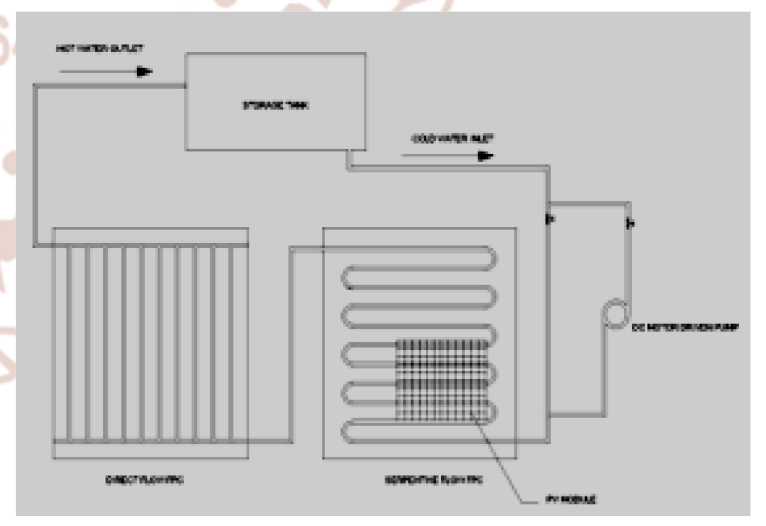

Fig 1. A schematic 2D diagram of series connected $\mathrm{PV} / \mathrm{T}$ system

The module temperature is greatly reduced by using clay. The results have exhibited a maximum increase of $19.4 \%$ to the output voltage and $19.1 \%$ to the output power[6]. High resistance of $\mathrm{PV} / \mathrm{T}$ system produce energy less than the energy consumption of 
International Journal of Trend in Scientific Research and Development (IJTSRD) ISSN: 2456-6470

pump. An account to overcome the problem, natural circulation is implemented various parameters. It is found that annual integrative efficiency is $60 \%$ [7].

\section{EXPERIMENTAL SETUP}

The setup consists of a storage tank which is connected to the PV module using UPVC pipes. The flow tubes fixed behind the module is made up of copper. The copper tubes are brazed in such a way that there is no leakage. Electrical components such as ammeter, voltmeter, rheostat and connecting wires are used for electrical connections.

The figure 1 depicts the schematic diagram of the $\mathrm{PV} / \mathrm{T}$ module connected in series. The inlet is given from the storage tank which is capable of storing 100 $\mathrm{L}$. The water enters into the first panel at $\mathrm{T}_{\mathrm{fi}}\left({ }^{\circ} \mathrm{C}\right)$ temperature. The outlet of the first panel is the inlet for the second panel. The outlet temperature of first panel is $\mathrm{T}_{\mathrm{fo} 1}\left({ }^{\circ} \mathrm{C}\right)$. The water passes from the top header of the first panel to the bottom header of the second panel.

The outlet of the second panel is $\mathrm{T}_{\mathrm{f} 02}\left({ }^{\circ} \mathrm{C}\right)$ and is passed into the storage tank again which contributes a closed system.

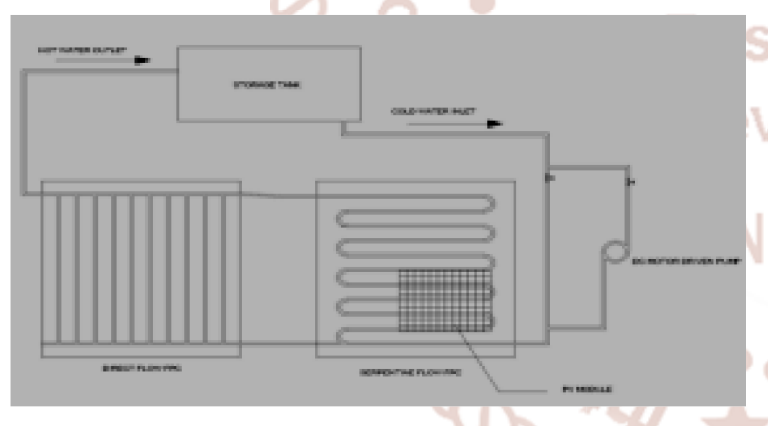

Fig 2. A schematic 2D diagram of parallel connected $\mathrm{PV} / \mathrm{T}$ system

The figure 2 depicts the schematic diagram of the $\mathrm{PV} / \mathrm{T}$ module connected in series. The inlet is given from the storage tank which is capable of storing 100 $\mathrm{L}$. The water enters into the first panel at $\mathrm{T}_{\mathrm{fi}}\left({ }^{\circ} \mathrm{C}\right)$ temperature. The outlet of the first panel is the inlet for the second panel. The outlet temperature of first panel is $\mathrm{T}_{\mathrm{f} 01}\left({ }^{\circ} \mathrm{C}\right)$. The water passes from the top header of the first panel to the top header and the bottom header of the first panel to the bottom header of the second panel.

The outlet of the second panel is $\mathrm{T}_{\mathrm{f} 02}\left({ }^{\circ} \mathrm{C}\right)$ and is passed into the storage tank again which also contributes a closed system.
IV. TECHNICAL SPECIFICATION

\begin{tabular}{|c|c|}
\hline COMPONENTS & SPECIFICATION \\
\hline \multicolumn{2}{|l|}{ ELECTRICAL } \\
\hline Ammeter & $(0-10) \mathrm{A}$ \\
\hline Voltmeter & $(0-60) \mathrm{V}$ \\
\hline Rheostat & $250 \Omega, 1.8 \mathrm{~A}$ \\
\hline Optimum Voltage & $18.2 \mathrm{~V}$ \\
\hline Optimum Current & $2.2 \mathrm{~A}$ \\
\hline Power & $40 \mathrm{~W}$ \\
\hline \multicolumn{2}{|l|}{ THERMAL } \\
\hline Thermocouple & K - Type \\
\hline RTD & $\mathrm{PT}-100$ \\
\hline Storage Tank & 100 litres capacity \\
\hline Working Liquid & Water \\
\hline Mass flow rate & $0.009 \mathrm{~kg} / \mathrm{s}$ \\
\hline \multicolumn{2}{|l|}{$\mathrm{PV} / \mathrm{T}$ MODULE } \\
\hline Company name & INNOVA \\
\hline Module weight & $4.9 \mathrm{~kg}$ \\
\hline PV Module & Poly c $-\mathrm{Si}$ \\
\hline $\begin{array}{l}\text { Optimum Circuit } \\
\text { Current }\end{array}$ & $2.20 \mathrm{~A}$ \\
\hline $\begin{array}{l}\text { Optimum Operating } \\
\text { Voltage }\end{array}$ & $18.2 \mathrm{~V}$ \\
\hline Module Area & $610 * 670 \mathrm{~mm}^{2}$ \\
\hline Open Circuit Voltage & $22.2 \mathrm{~V}$ \\
\hline Short Circuit Current & $2.37 \mathrm{~A}$ \\
\hline Shunt Resistance & $236.99 \Omega$ \\
\hline Fill Factor & $76.11 \%$ \\
\hline Tube Inner Diameter & $12.75 \mathrm{~mm}$ \\
\hline Tube Outer Diameter & $16 \mathrm{~mm}$ \\
\hline Tube Material & Copper \\
\hline Pipe Material & CPVC \\
\hline
\end{tabular}

\section{FORMULA USED}

The fill factor of the module for various time is calculated by the following formula

$$
\mathrm{F} . \mathrm{F}=\frac{\mathrm{I}_{\mathrm{L}} * \mathrm{~V}_{\mathrm{L}}}{\mathrm{I}_{\mathrm{SC}} * \mathrm{~V}_{\mathrm{OC}}}
$$

The electrical power is determined by the formula

$$
\mathrm{P}=\mathrm{I}_{\mathrm{SC}} * \mathrm{~V}_{\mathrm{OC}}
$$


International Journal of Trend in Scientific Research and Development (IJTSRD) ISSN: 2456-6470

The heat generated can be found by using

The thermal efficiency for the system can be found by

$\mathrm{Q}=\mathrm{m}^{*} \mathrm{C}_{\mathrm{p}} *\left(\mathrm{~T}_{\mathrm{in}}-\mathrm{T}_{\mathrm{f} 02}\right)$

$$
\eta_{\mathrm{t} \text { per panel }}=\frac{\mathrm{m} * \mathrm{C}_{\mathrm{p}} *}{\mathrm{~N}_{\mathrm{m}} * \mathrm{~A}_{\mathrm{m}} * \mathrm{I}_{\mathrm{t}}} *\left(\mathrm{~T}_{\mathrm{in}}-\mathrm{T}_{\mathrm{f} 02}\right)
$$

The electrical efficiency for the system can be determined by

The overall efficiency of the system is obtained using

$\eta_{\text {e per panel }}=\frac{\mathrm{I}_{\mathrm{SC}} * \mathrm{~V}_{\mathrm{OC}} * \mathrm{~F} . \mathrm{F}}{\mathrm{N}_{\mathrm{m}} * \mathrm{~A}_{\mathrm{m}} * \mathrm{I}_{\mathrm{t}}}$

$$
\eta=\eta_{\mathrm{e}}+\eta_{\mathrm{t}}
$$

\section{READINGS AND TABULATIONS}

Table 2. Electrical and thermal readings taken on 28.02.2018 of the PV/T system connected in series.

\begin{tabular}{|c|c|c|c|c|c|c|c|c|c|c|c|c|}
\hline TIME & $\mathrm{T}_{\mathrm{a}}$ & $\mathrm{I}_{\mathrm{L}}$ & $\mathrm{V}_{\mathrm{L}}$ & $\mathrm{I}_{\mathrm{SC}}$ & $\mathrm{V}_{\mathrm{OC}}$ & $\mathrm{I}_{\mathrm{r}}$ & $\mathrm{F} . \mathrm{F}$ & $\mathrm{T}_{\mathrm{fi}}$ & $\mathrm{T}_{\mathrm{f} 01}$ & $\mathrm{~T}_{\mathrm{f} 02}$ & $\eta_{\mathrm{t}_{\text {per panel }}}$ & $\begin{array}{c}\eta_{\mathrm{e} \text { per }} \\
\text { panel }\end{array}$ \\
\hline hours & ${ }^{\circ} \mathrm{C}$ & $\mathrm{A}$ & $\mathrm{V}$ & $\mathrm{A}$ & $\mathrm{V}$ & $\mathrm{W} / \mathrm{m}^{2}$ & no unit & ${ }^{\circ} \mathrm{C}$ & ${ }^{\circ} \mathrm{C}$ & ${ }^{\circ} \mathrm{C}$ & $\%$ & $\%$ \\
\hline $10: 00$ & 24.5 & 1.5 & 15 & 2.1 & 40 & 772 & 0.26786 & 30 & 30.2 & 32.3 & 14.3144 & 3.5656 \\
\hline $11: 00$ & 28 & 2 & 30 & 2.4 & 38 & 920 & 0.65789 & 30.7 & 31.8 & 34.3 & 18.8008 & 7.9786 \\
\hline $12: 00$ & 30.5 & 2 & 30 & 2.3 & 37 & 1083 & 0.70505 & 33.7 & 34.4 & 37.1 & 15.0838 & 6.7778 \\
\hline $13: 00$ & 29 & 1.8 & 30 & 2.2 & 38 & 1110 & 0.64593 & 36.7 & 37.5 & 40 & 14.2841 & 5.9516 \\
\hline $14: 00$ & 30 & 1.5 & 30 & 1.8 & 36 & 980 & 0.69444 & 39.2 & 39.5 & 41.5 & 11.2762 & 5.6176 \\
\hline $15: 00$ & 29.5 & 1 & 30 & 1.2 & 36 & 720 & 0.69444 & 40.9 & 41.4 & 42.8 & 12.6789 & 5.0975 \\
\hline $16: 00$ & 31 & 0.6 & 25 & 0.7 & 36 & 610 & 0.59524 & 39.9 & 40.1 & 40.8 & 7.0888 & 3.0083 \\
\hline
\end{tabular}

The above table infers the Electrical and thermal readings taken on 28.02.2018 of the PV/T system connected in series.

Table 3. Electrical and thermal readings taken on 27.02.2018 of the PV/T system connected in parallel

\begin{tabular}{|c|c|c|c|c|c|c|c|c|c|c|c|c|}
\hline TIME & $\mathrm{T}_{\mathrm{a}}$ & $\mathrm{I}_{\mathrm{L}}$ & $\mathrm{V}_{\mathrm{L}}$ & $\mathrm{I}_{\mathrm{SC}}$ & $\mathrm{V}_{\mathrm{OC}}$ & $\mathrm{I}_{\mathrm{R}}$ & $\mathrm{F} . \mathrm{F}$ & $\mathrm{T}_{\mathrm{fi}}$ & $\mathrm{T}_{\mathrm{f} 01}$ & $\mathrm{~T}_{\mathrm{f} 2}$ & $\eta_{\mathrm{t} p e r}$ panel & $\eta_{\mathrm{e} \text { per panel }}$ \\
\hline hours & ${ }^{\circ} \mathrm{C}$ & $\mathrm{A}$ & $\mathrm{V}$ & $\mathrm{A}$ & $\mathrm{V}$ & $\mathrm{W} / \mathrm{m}^{2}$ & no unit & ${ }^{\circ} \mathrm{C}$ & ${ }^{\circ} \mathrm{C}$ & ${ }^{\circ} \mathrm{C}$ & $\%$ & $\%$ \\
\hline $10: 00$ & 26 & 0.9 & 15 & 1.1 & 20 & 780 & 0.61364 & 30 & 30.5 & 32.4 & 14.7835 & 2.1174 \\
\hline $11: 00$ & 28.5 & 4.9 & 15 & 5.5 & 18 & 944 & 0.74242 & 31.8 & 32.8 & 35.5 & 18.8318 & 9.5253 \\
\hline $12: 00$ & 28 & 4.4 & 15 & 5 & 18 & 1072 & 0.73333 & 32.8 & 33.8 & 36.9 & 18.3760 & 7.5321 \\
\hline $13: 00$ & 29 & 3.9 & 15 & 4.7 & 18 & 1115 & 0.69149 & 36.4 & 36.7 & 39.9 & 15.0819 & 6.4187 \\
\hline $14: 00$ & 30.5 & 3.4 & 15 & 3.8 & 17.5 & 980 & 0.76692 & 37.9 & 38.8 & 40.8 & 14.2178 & 6.3666 \\
\hline $15: 00$ & 30 & 2.6 & 15 & 3 & 18.5 & 700 & 0.70270 & 38.1 & 38.4 & 40 & 13.0412 & 6.8160 \\
\hline $16: 00$ & 29 & 2 & 15 & 2.3 & 18.5 & 560 & 0.71351 & 38.4 & 38.6 & 39.3 & 7.7218 & 6.6325 \\
\hline
\end{tabular}


The above table Electrical and thermal readings taken on 27.02.2018 of the PV/T system connected in parallel.

\section{RESULTS AND DISCUSSIONS}

\section{A. Series system}

Graph 1 represents the variation of thermal efficiency of the module with respect to time. It was seen from the graph that it was maximum at $11 \mathrm{am}$.

Graph 2 represents the variation of electrical efficiency of the module with respect to time. It was seen from the graph that it was maximum at $11 \mathrm{am}$.

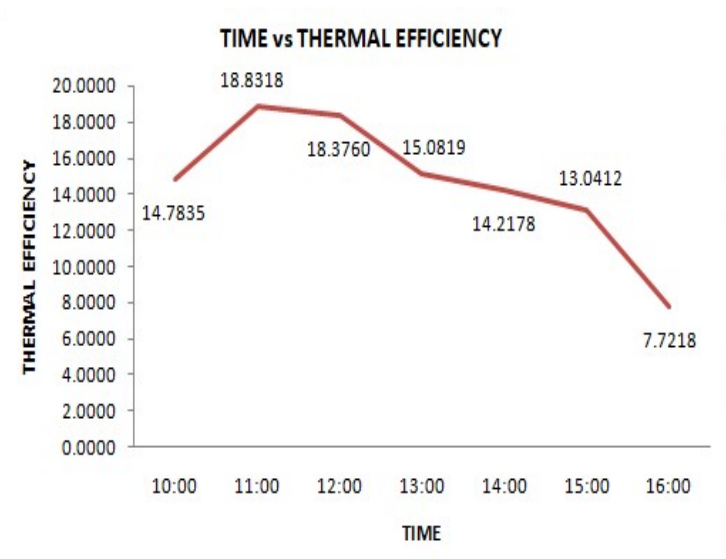

Graph 3. Time vs. thermal efficiency

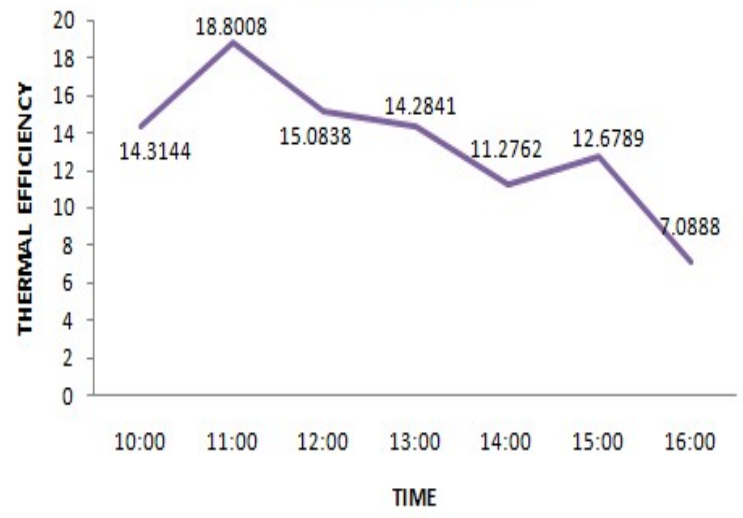

Graph 1. Time vs. thermal efficiency TINE vs ELECTRICAL EFFICIENCY

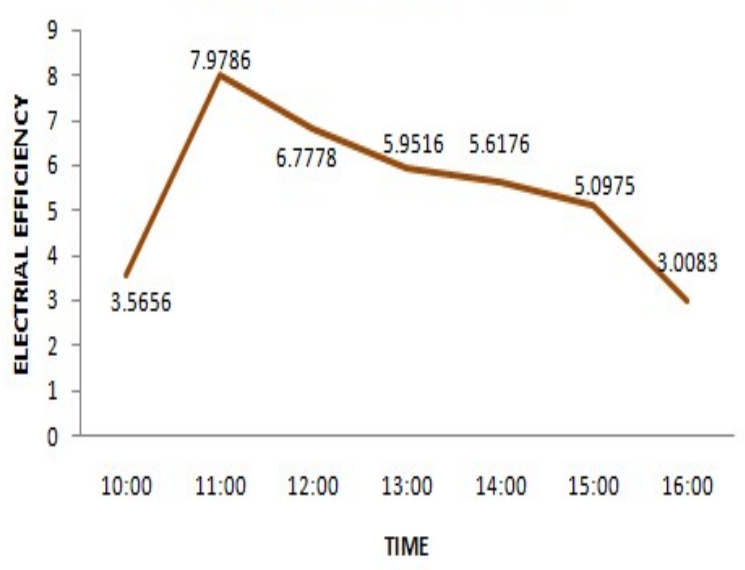

Graph 2. Time vs. electrical efficiency

\section{B. Parallel system}

Graph 3 represents the variation of thermal efficiency of the module with respect to time. It was seen from the graph that it was maximum at $11 \mathrm{am}$.

Graph 4 represents the variation of electrical efficiency of the module with respect to time. It was seen from the graph that it was maximum at $11 \mathrm{am}$.

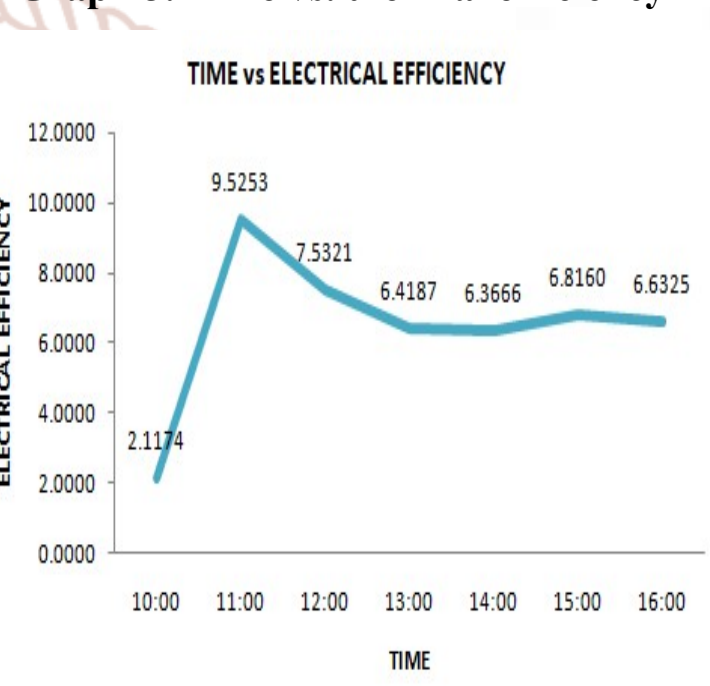

Graph 4. Time vs. electrical efficiency

\section{CONCLUSIONS}

The main factors which are responsible for the maximum efficiency are the ambient temperature, mass flow rate and the irradiance. More the temperature difference between inlet and outlet of water, the more heat transfer is obtained. Increase in mass flow rate of the water increases the module efficiency. As a result of the experiment, the parallel connected $\mathrm{PV} / \mathrm{T}$ system can produce power $12.12 \%$ higher than the series connected system.

\section{FUTURE WORK}

In order to obtain maximum efficiency proper maintenance of module should be taken. Thermal degradations like excessive heat of the module, dust accumulation, module angle from the ground are to be maintained. Effective insulation for the copper tubes, effective cooling technique and mass flow rate of the 
water can increase the module performance thus increases the efficiency.

\section{NOMENCLATURE}

- $\mathrm{T}_{\mathrm{a}}$ - Ambient temperature $\left({ }^{\circ} \mathrm{C}\right)$

- $\mathrm{T}_{\mathrm{i}}$-Inlet temperature $\left({ }^{\circ} \mathrm{C}\right)$

- $\mathrm{T}_{\mathrm{f} 01}$ - Outlet temperature $1\left({ }^{\circ} \mathrm{C}\right)$

- $\mathrm{T}_{\mathrm{f} 02}$-Outlet temperature $2\left({ }^{\circ} \mathrm{C}\right)$

- Q-Heat rate (Watt)

- $\mathrm{m}$ - Mass flow rate $(\mathrm{kg} / \mathrm{s})$

- $\mathrm{I}_{\mathrm{sc}}-$ Short circuit current (Ampere)

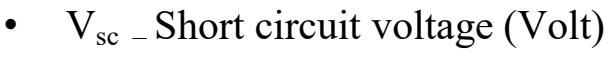

- $\mathrm{I}_{\mathrm{L}}$ - Line current (Ampere)

- $\mathrm{V}_{\mathrm{L}-}$ Line voltage (Volt)

- $\quad \mathrm{P}_{-}$Electric power (Watt)

- $\eta_{t-}$ Thermal efficiency (\%)

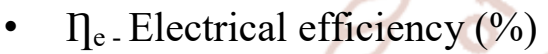

- ח-Overall efficiency (\%)

- $\mathrm{I}_{\mathrm{r}}$ - Irradiance $\left(\mathrm{W} / \mathrm{m}^{2}\right)$

- F.F - Fill Factor (no unit)

- $\mathrm{N}_{\mathrm{m}}-$ Number of modules

- $\mathrm{A}_{\mathrm{m}}-$ Area of the module

\section{REFERENCES}

1. Shiv Kumar, Gajendra Singh, Tiwari.G.N \& Yadav.J.K.,2011. Thermal modelling of a hybrid photovoltaic thermal water heater in parallel configuration. International journal of Sustainable energy iFirst, 2012,1-19.

2. Sanaz Ghazi, Ali Sayigh, Kenneth Ip.,2014. Dust effect on flat surfaces - A review paper. Renewable and Sustainable Energy Reviews 33(2014)742-751.

3. Siecker.J, Kusakana.K, Numbi.B.P., 2017. A review of solar photovoltaic systems cooling technologies. Renewable and Sustainable Energy Reviews 79 (2017) 192-203.

4. Teo.H.G, Lee.P.S, Hawlader,M,N,A., 2011. An active cooling system for photovoltaic modules.Applied energy 90 (2012) 309-315.

5. Ali H.A. Al-Waeli.,et al., 2017. An experimental investigation of $\mathrm{SiC}$ nanofluid as a base-fluid for a photovoltaic thermal PV/T system. Energy Conservation and Management 142 (2017) 547558.

6. Abdul Hai Alami.,2014. Effects of evaporative cooling on efficiency of photovoltaic modules. Energy Conversion and Management 77 (2014) 668-679.

7. Arunkumar. G | Dr. P. Navaneetha Krishnan "Experimental Enhancement of Heat Transfer Analysis on Heat Pipe using $\mathrm{SiO} 2$ and $\mathrm{TiO} 2 \mathrm{Nano}$ Fluid" Published in International Journal of Trend in Scientific Research and Development (ijtsrd), ISSN: 2456-6470, Volume-2 | Issue-4, June 2018

8. Qi Shi, Jian, Chunmei Guo, and Bin Zheng., 2017. Experimental and simulation analysis of a $\mathrm{PV} / \mathrm{T}$ system under the pattern of natural circulation.S1359-4311(16)32014-2 (Accepted Manuscript). 